\title{
Article \\ Biological activity studies of Sensevieria hyacinthoides extracts
}

\author{
Mohammad Emdadul Islam ${ }^{1}$, Tofail Ahmed Chowdhury ${ }^{2}$, Nasim Sultana ${ }^{3}$, Abul Hasnat Muhammad Solaiman ${ }^{4 *}$ \\ and S M Anamul Arefin ${ }^{5}$ \\ ${ }^{1}$ Department of Chemistry, Habibullah Bahar College, Dhaka, Bangladesh \\ ${ }^{2}$ Department of Chemistry, University of Dhaka, Bangladesh \\ ${ }^{3}$ Analytical Research Division, BCSIR Laboratories, Dr. Qudrat-i-Khuda Road, Dhaka, Bangladesh \\ ${ }^{4}$ Department of Horticulture, Sher-e-Bangla Agricultural University, Dhaka-1207, Bangladesh \\ ${ }^{5}$ Fab Lab SAU, Sher-e-Bangla Agricultural University, Dhaka-1207, Bangladesh
}

*Corresponding author: Professor Dr. Abul Hasnat Muhammad Solaiman, Department of Horticulture, Sher-eBangla Agricultural University, Dhaka-1207, Bangladesh. E-mail: solaimansau@gmail.com

Received: 10 March 2020/Accepted: 23 April 2020/ Published: 30 April 2020

\begin{abstract}
Biological activity was studied of the different solvent extracts such as n-hexane, ethyl acetate, nbutanol, and methanol extracts of the rhizomes of Sensevieria hyacinthoides. The cytotoxic potential were examined by using brine shrimp lethality bioassay. Ethyl acetate extract exhibited quite potent activity in brine shrimp lethality bioassay with $\mathrm{LC}_{50} 1.95 \mu \mathrm{g} / \mathrm{mL}$, respectively. These result suggested that it might contain antitumor or cytotoxic agent. The ethyl acetate extract showed significant free radical scavenging activity with $\mathrm{IC}_{50} 10.51 \mu \mathrm{g} / \mathrm{mL}$ and demonstrated excellent antibacterial activity. The free radical scavenging activity of the solvent extracts (n-hexane, ethyl acetate and n-butanol) were assayed by using DPPH method. The $\mathrm{IC}_{50}$ for Vit-c (Ascorbic acid) and ethyl acetate extract were found to be 3.91 and $10.51 \mu \mathrm{g} / \mathrm{mL}$, respectively.
\end{abstract}

Keywords: antibacterial screening; bioassay; cytotoxicity; free radical scavengers; Sensevieria hyacinthoides

\section{Introduction}

A good number of medicinal plants are used for the treatment of sexual transmitted Infections such as gonorrhea, syphilis, herpes etc and other infectious diseases by traditional practitioners in Bangladesh. $S$. hycenthoides commonly called as mother-in-law's tongue, devil's tongue, jinn's tongue, bow string hemp, snake plant and snake tongue and some of them such as $S$. hycenthoides, S. roxburghiana etc. so far never been chemically investigated in details. These species under took the investigation to find the presence of ingredients which have cytotoxic, antimicrobial and antioxidant activities view to justifying their usage.

General bioassays that are capable of detecting board spectrum of bioactivity present in crude extracts are brine shrimp lethality bioassay (BSLT) and free radical scavenging activity test (FRST). Both techniques are easily mastered, low cost, and needs small amount of test material. BSLT is predictive cytotoxicity and pesticidal activity (Ghisalberti et al., 1993). This test has been introduced in 1982 (Meyer et al., 1983) and employed for bioassay-guide fractionation of active cytotoxic and antitumor agents such as trilobacin from the bark of Asimina triloba (Zhao et al., 1992) and cis-annonacin from Annona muricata (Rieser et al., 1996). In Bangladesh and South Africa, S. hyacinthoides is grown in home gardens as an ornamental, medicinal, and spiritual plant (Ghani, 2003; Zobolo and Mkabela, 2006; Sultana et al., 2011; Maroyi and Mosina, 2014; Semenya and Potgieter, 2014; Mosina et al., 2015). The leaves and roots of $S$. hyacinthoides are marketed as herbal medicines in the Eastern Cape and KwaZulu-Natal provinces in South Africa (Cunningham, 1993; Dold and Cocks, 2002). In addition, FRST is also predictive of antioxidant activity and introduced in 1958 (Blois, 1958) and employed for the detection of active free radical scavengers like vitamin-c, vitamin E, flavonoids, carotenes, phenolic acids, phytate and phytoestrogens have been recognized as having the potential 
to reduce disease risk (Bendich and Langseth, 2001). There are a number of clinical studies suggesting that the antioxidants in fruits, vegetables, tea and red wine are the main factors for the observed efficacy of these foods in reducing the incidence of chronic diseases including heart disease and some cancers (Miller et al., 2000). $S$. hycenthoides (Common name-Murba; Synonyms- S.; Family-Agavaceae) is found in Bangladesh, India, Africa, Indonesia etc. (Schaffner, 1930). In Bangladesh, S. hycenthoides are wildly distributed in Gazipur, Savar and Tangail. This plant is administered as a cooling medicine; given for the treatment of gonorrhea, purgative, tonic, expectorant and febrifugic etc (Waricky and Hoehne, 1951). S. hyacinthoides is a succulent, robust, evergreen, stemless, and perennial herb which can grow up to $60 \mathrm{~cm}$ in height (Mwachala and Mbugua, 2007). S. hyacinthoides has fleshy creeping rhizomes that are sturdy, fibrous, and bright orange in color. The leaves are erect, rigid, loosely clustered, fibrous, flat, and arising from a horizontal underground rhizome. The leaves are lanceolate or narrowly elliptic in shape, the apex acute or obtuse, the blade leathery and dull green but mottled transversely with numerous more or less obscure pale green bands and the margins with a fine reddish line. The inflorescence is a many-flowered raceme, with stalkless flowers that are white, cream-colored or greenish-white to pale mauve in color. The flowers form small berry-like fruits, which are green at first, gradually becoming yellow when they ripen (Maoyi, 2019).

Therefore, the present study was undertaken with an objective to evaluate the cytotoxic, antibacterial and antioxidant activities of the solvent extracts of S. hycenthoides.

\section{Materials and Methods}

\subsection{Collection of plant material}

Fresh rhizomes of $S$. hycenthoides were collected from Gazipur in October, 2009 and identified by the taxonomist of Bangladesh National Herbarium, Dhaka, where a voucher specimen (No. 31563) has been deposited.

\subsection{Preparation of the solvent extracts (cold extraction)}

Freshly collected rhizomes of $S$. hycenthoides were dried in an oven at $38^{\circ} \mathrm{C}$ and crushed in pieces. The crushed powder $(390 \mathrm{~g})$ was extracted with methanol for 5 days. The extract was concentrated to gummy mass $(45.9 \mathrm{~g})$ using Buchi Rotary Evaporator, USA. The methanol extract $(13.8 \mathrm{~g})$ was then partitioned by separatory funnel by using $\mathrm{n}$-hexane, followed by ethyl acetate and $\mathrm{n}$-butanol. These extracts were then concentrated by using rotary vacuum evaporator to provide $\mathrm{n}$-hexane $(5.0 \mathrm{~g})$, ethyl acetate $(3.2 \mathrm{~g})$, $\mathrm{n}$-butanol $(3.4 \mathrm{~g})$ and water $(5.8 \mathrm{~g})$.

\subsection{General experimental procedure}

The UV absorbance was performed with a PerkinElmer Shelton, CT 06484 USA, Lambda 25 UV/VIS spectrometer. Vacuum rotary evaporator (BUCHI, Rotavapor R-210 Switzerland) was used for evaporating solvents. All solvents were of analytical grade and obtained from commercial sources (Sigma-Aldrich, St. Louis, MO, USA).

\subsection{Cytotoxicity bioassays}

The cytotoxic activity was performed by brine shrimp lethality bioassay method (Meyer et. al., 1983). The test samples for crude $\mathrm{MeOH}$ extracts as well as n-hexane (4.0 g), ethyl acetate $(2.2 \mathrm{~g}), \mathrm{n}$-butanol $(2.4 \mathrm{~g})$ and water (3.8 g) extract were dissolved in DMSO and serial dilution were made as 100, 50, 25, 12.5, 6.25, 3.125, 1.563, 0.781 and $0.3095 \mu \mathrm{g} / \mathrm{mL}$. Vincristine sulphate (positive control) was dissolved in DMSO and serial dilution were made as $20,10,5,2.5,1.25,0.625,0.3125,0.15625,0.0781 \mu \mathrm{g} / \mathrm{mL}$. Then each of these test solutions was added to test tubes containing 12 shrimps in simulated brine water $(5 \mathrm{~mL})$ and incubated at room temperature for $24 \mathrm{~h}$. After $24 \mathrm{~h}$, the median lethal concentration $\left(\mathrm{LC}_{50}\right)$ of the test samples was determined by a plot of percentage the shrimps against the logarithm of the sample concentrations (Finney method; Finney, 1952). Vincristine sulphate $\left(\mathrm{LC}_{50}=0.52\right)$ was used as positive control in this assay to compare the cytotoxicity of the test samples. Results are presented in Table 1.

\subsection{Antibacterial screening}

The test samples were dissolved separately in specific volume of chloroform or methanol depending their solubility. The antibacterial screening was then carried out by the disc diffusion method (Barry, 1980; Bauer, 1996). The diluted samples were applied on to sterile blank discs (Oxoid, UK) at a concentration of 100 (g/disc for this test where Streptomycin $10 \mathrm{~g} /$ disc, Oxoid, UK) used as a standard. Results are presented in Table 2. 


\subsection{Free radical scavenging activity}

The free radical scavenging activity was assayed spectrophotometrically by DPPH method (Rieser et al., 1996). The DPPH (2,2-Diphenyl-1-picrylhydrazyl) radical has a deep violet color due to its unpaired electron and radical scavenging activity can be followed spectrophotometrically by a loss of absorbance at $525 \mathrm{~nm}$. Sample stock solutions $(1 \mathrm{mg} / \mathrm{mL})$ were diluted to final concentrations of $100,50,10,5$ and $1(\mathrm{~g} / \mathrm{mL}$ in $70 \%$ ethanol or DMSO. DPPH ethanol solution $(0.2 \mathrm{mM}, 0.5 \mathrm{~mL})$ was added to $1 \mathrm{~mL}$ of sample solutions of different concentrations, shaken well by vortex and allowed to react at room temperature. The absorbance values were measured after $10 \mathrm{~min}$ at $525 \mathrm{~nm}$ by UV/Vis spectrophotometer. The free radical scavenging activity of samples was calculated according to the formula:

DPPH radical scavenging activity $(\%)=[1-($ Abs sample-Abs blank $) /$ Abs control $] \times 100$

Where, Abs sample is the absorbance of the experimental sample, Abs blank is the absorbance of the blank, Abs control is the absorbance of the control.

As a blank, $70 \%$ EtOH or DMSO solvent $(0.5 \mathrm{~mL})$ and sample solution $(1.0 \mathrm{~mL})$ were used. DPPH solution $(0.5$ $\mathrm{mL}, 0.2 \mathrm{mM})$ and $70 \% \mathrm{EtOH}$ or DMSO solvent $(1.0 \mathrm{ml})$ was used as a negative control. The ascorbic acid (vitamin C) was used as a positive control. Each treatment was replicated thrice. Results are presented in (Figure 1).

\section{Results and discussion}

The cytotoxic activity of the different solvent extracts were determined by using brine shrimp lethality bioassay. The $\mathrm{LC}_{50}$ for vincristine sulphate (positive control), $\mathrm{n}$-hexane, ethyl acetate and $\mathrm{n}$-butanol extract obtained from Finney method were found to be $0.52,4.89,1.95,10.69$ and $12.51 \mu \mathrm{g} / \mathrm{mL}$, respectively (Table 1 ). In comparison with the positive control (vincristine sulphate), it is mentioned that all the test samples were lethal to brine shrimp nauplii. However, ethyl acetate extract $\left(\mathrm{LC}_{50} 1.95\right)$ demonstrated quite potent activity in brine shrimp lethality bioassay. These positive results suggested that they may contain antitumor or pesticidal active compounds.

It needs to add that Tkachenko et al. (2017a) evaluated the antioxidant activities of leaf extracts of $S$. hyacinthoides by assessing their in vitro effects against protein damage in equine erythrocytes using the OMP assay. The extracts reduced the concentration of ketonic derivatives of OMP when compared to untreated erythrocytes by $13.4 \%$ (Tkachenko et al., 2017a). Similarly, Tkachenko et al. (2017b) evaluated the antioxidant activities of leaf extracts of $S$. hyacinthoides by assessing the level of 2-thiobarbituric acid reactive substances (TBARS) as biomarkers of lipid peroxidation in equine erythrocyte suspension induced by treatment of the leaf extracts. The leaf extracts resulted in a significant increase of $29.7 \%$ of TBARS concentration in erythrocytes. These results suggest that $S$. hyacinthoides has a promising antioxidant and prooxidant potential.

The antibacterial activity of different solvent extracts were subjected to screening at $100 \mu \mathrm{g} / \mathrm{disc}$ of seven types of bacteria by using disc diffusion method. The moderate to good zone of inhibition exhibited by ethyl acetate (EE) and n-butanol (BE) extract against almost all tested pathogenic microorganisms having the zone of inhibition of $9 \pm 1 \mathrm{~mm}$ each (Table 2).

In the study conducted by Poonam Sethi (2013), the ethanolic extract of rhizome of Sansevieria roxburghiana plant displayed remarkable antibacterial activity against the four pathogenic bacteria, Salmonella typhi, Pseudomonas fluorescens, Pseudomonas aeruginosa, and Escherichia coli. Maximum activity was seen in the case of Pseudomonas fluorescens where the zone inhibition diameter was $32 \mathrm{~mm}(300 \mu \mathrm{g} / \mathrm{ml})$. The MIC study revealed that the value for the Salmonella typhi and Escherichia coli as 80 and $60 \mu \mathrm{g} / \mathrm{ml}$ for Pseudomonas fluorescens and Pseudomonas aeruginosa (Poonam Sethi, 2013). Hanumanth Kumar and Pramoda Kumari (2015) reported about potential bioactive secondary metabolites and revealed the possible antimicrobial activities of leaf extracts of Sansevieria roxburghiana. Antimicrobial screening revealed significant antimicrobial activity against Proteus vulgaris, Salmonella typhi, Pseudomonas aeruginosa, Klebsiella pneumoniae, and Escherichia coli (Hanumanth Kumar and Pramoda Kumari, 2015). Furthermore, qualitative analysis, conducted by these authors, confirmed the presence of various primary and secondary plant metabolites such as alkaloids, terpenoids, flavonoids, saponins, steroids, phenols, tannins, and quinine in selected parts of Sansevieria roxburghiana (Tkachenko et al., 2017c).

The free radical scavenging activity of the solvent extracts (n-hexane, ethyl acetate and n-butanol) were assayed by using DPPH method. The $\mathrm{IC}_{50}$ for Vit-c (Ascorbic acid) and ethyl acetate extract were found to be 3.91 and $10.51 \mu \mathrm{g} / \mathrm{mL}$ respectively (Figure 1). In comparison with the positive control (ascorbic acid), it showed significant antioxidant activity exhibited by the crude ethyl acetate extract. These findings suggest that the EtoAc extract may contain flavonoid/phenolic compounds which have the antitumor potentials. 
Table 1. Cytotoxic effects of the solvent extracts of $S$. hycenthoides on brine shrimp nauplii.

\begin{tabular}{|c|c|c|c|c|c|c|c|c|c|c|c|c|c|}
\hline \multirow{2}{*}{$\begin{array}{l}\text { Conc. } \\
(\mathrm{C}) \\
(\mu \mathrm{g} / \mathrm{ml})\end{array}$} & \multirow[t]{2}{*}{$\log C$} & \multicolumn{4}{|c|}{ \% Mortality } & \multicolumn{4}{|c|}{$\mathbf{L C}_{50}(\mu \mathrm{g} / \mathrm{mL})$} & \multicolumn{4}{|c|}{ Vincristine sulphate } \\
\hline & & $\begin{array}{l}\text { Sh. } \\
\text { He }\end{array}$ & $\begin{array}{l}\text { Sh. } \\
\text { EA }\end{array}$ & $\begin{array}{l}\text { Sh } \\
\text { Bu }\end{array}$ & $\begin{array}{l}\text { Sh. } \\
\text { Me }\end{array}$ & $\begin{array}{l}\text { Sh. } \\
\text { He }\end{array}$ & $\begin{array}{l}\text { Sh. } \\
\text { EA }\end{array}$ & Sh. Bu & Sh. Me & $\begin{array}{l}\text { Conc. } \\
(\mathrm{C}) \\
(\mu \mathrm{g} / \mathrm{ml})\end{array}$ & $\log C$ & $\begin{array}{l}\% \\
\text { Mortality }\end{array}$ & $\begin{array}{l}\mathbf{L C}_{50} \\
(\mu \mathrm{g} / \mathrm{mL})\end{array}$ \\
\hline 100 & 2.602 & 100 & 100 & 100 & 100 & & & & & 20 & 1.3 & 100 & \\
\hline 50 & 2.301 & 100 & 100 & 100 & 90 & & & & & 10 & 1 & 100 & \\
\hline 25 & 2 & 90 & 100 & 85 & 67 & & & & & 5 & 0.698 & 90 & \\
\hline 12.5 & 1.699 & 67 & 90 & 33 & 50 & & & & & 2.5 & 0.397 & 80 & \\
\hline 6.25 & 1.398 & 58 & 80 & 25 & 30 & & & & & 1.25 & 0.096 & 70 & \\
\hline 3.125 & 1.097 & 33 & 58 & 17 & 18 & & & & & 0.625 & -0.204 & 60 & \\
\hline 1.563 & 0.796 & 25 & 50 & 8 & 0 & & & & & 0.3125 & -0.488 & 40 & \\
\hline 0.781 & -0.107 & 8 & 33 & 0 & 0 & 4.89 & 1.95 & 10.69 & 12.51 & 0.1563 & -0.806 & 20 & 0.52 \\
\hline 0.3905 & -0.408 & 0 & 8 & 0 & 0 & & & & & 0.078 & -1.107 & 10 & \\
\hline
\end{tabular}

$\mathrm{Sh} . \mathrm{He}=\mathrm{n}$ - Hexane extract of $S$. hycenthoides, Sh. EA = Ethyl acetate extract of $S$. hycenthoides, $\mathrm{Sh} . \mathrm{Bu}=\mathrm{n}$-Butanol extract of $S$. hycenthoides, Sh. Me = Methanol extract of $S$. hycenthoides

Table 2. Antibacterial test results of the solvent extract of $S$. hycenthoides.

\begin{tabular}{|c|c|c|c|c|c|c|c|}
\hline \multirow{2}{*}{$\begin{array}{l}\text { Material } \\
\text { tested }\end{array}$} & \multicolumn{7}{|c|}{ MIC $(\mu \mathrm{g} /$ disc $)$, diameter in $\mathrm{mm}$} \\
\hline & B. cereus & B. megaterium & B. subtilis & S. aureus & E. coli & S. sonnei & S. dysenteriae \\
\hline $\begin{array}{l}\text { MSh } \\
100 \mu \mathrm{g} / \mathrm{disc}\end{array}$ & 12 & 8 & 8 & 8 & 12 & 8 & 7 \\
\hline $\begin{array}{l}\text { HSh } \\
100 \mu \mathrm{g} / \mathrm{disc}\end{array}$ & NA & 7 & 12 & 12 & 6 & 5 & NA \\
\hline $\begin{array}{l}\text { ESh } \\
100 \mu \mathrm{g} / \mathrm{disc}\end{array}$ & 11 & 7 & 13 & 12 & 11 & NA & 8 \\
\hline $\begin{array}{l}\text { BSh } \\
100 \mu \mathrm{g} / \mathrm{disc}\end{array}$ & 12 & NA & 7 & 8 & NA & 7 & NA \\
\hline $\begin{array}{l}\text { Streptomycin } \\
10 \mu \mathrm{g} / \text { disc }\end{array}$ & 22 & 23 & 17 & 18 & 28 & 18 & 27 \\
\hline
\end{tabular}

$\mathrm{MSh}=\mathrm{MeOH}$ extract, $\mathrm{HSh}=\mathrm{Hexane}$ extract, $\mathrm{ESh}=\mathrm{EA}$ extract, $\mathrm{BSh}=\mathrm{BuOH}$ extract,

$\mathrm{MIC}=$ Minimum Inhibitory Concentration

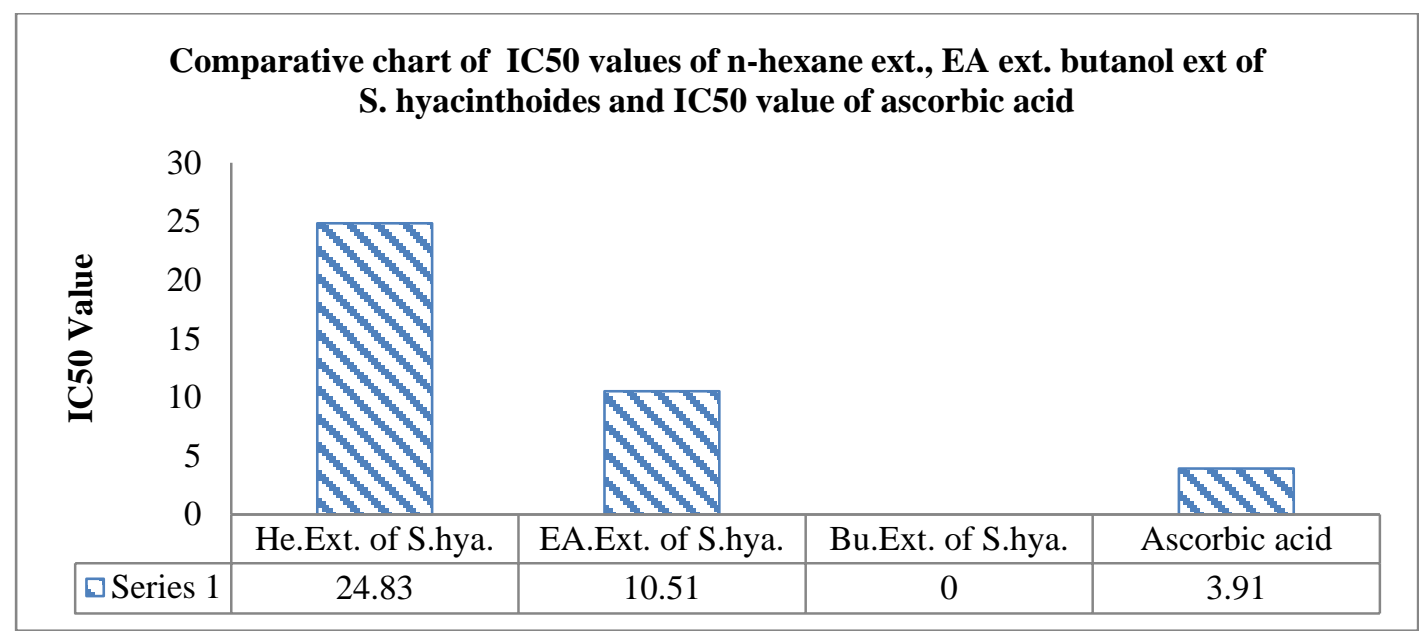

Figure 1. Comparative study of different crude extract of Sensevieria hyacinthoides and ascorbic acid.

\section{Conclusions}

It is concluded that the antioxidant, antibacterial and cytotoxicity screening of the different solvent extracts were found to be consistent with the folk uses of $S$. hyacinthoides by local people. In the present study, it can be mentioned that only the ethyl acetate extract of $S$. hyacinthoides demonstrated excellent cytotoxic, antibacterial and free radical scavenging activity among the extracts. So, the above findings are recommended for the further investigation of the ethyl acetate part to evaluate active phytoconstituents. 


\section{Acknowledgements}

We are grateful to the International Foundation for Science (IFS) and Organization for Prohibition of Chemical Weapons (OPCW) for their financial support. We are also thankful to the National University, Gazipur, Bangladesh and the Bangladesh Council of Scientific and Industrial Research (BCSIR), Dhaka, Bangladesh.

\section{Conflict of interest}

None to declare.

\section{References}

Barry AL, 1980. Procedures for testing antimicrobial agents in agar media," In: Antibiotics in Laboratory Medicines, Williams and Wilkins Co., Baltimore, USA.

Bauer AW, WMM Kirby, JC Sherris and M Turck, 1966. Antibiotic susceptibility testing by a standard single disc method, Am. J. Clin. Pathol., 45: 493-496.

Bendich A and L Langseth, 2001. The health effects of vitamin C supplementation: a review, J. Am. Coll. Nutr., 14: 124-36.

Blois MS, 1958. Antioxidant determination by the use of a stable free radical. Nature, 29:1199-1200.

Cunningham AB, 1993. African Medicinal Plants: Setting Priorities at the Interface between Conservation and Primary Health Care. Paris: People and Plants Working Paper 1, UNESCO; p. 30.

Dold AP and ML Cocks, 2002. The trade in medicinal plants in the Eastern Cape province, South Africa. S. Afr. J. Sci., 98: 589-597.

Finney DJ and F Tattersfield, 1952. Probit analysis. Cambridge England; Expected 1. New York, NY, USA: Cambridge University Press.

Ghani A, 2003. Medicinal Plants of Bangladesh with Chemical Constituents and Uses. Dhaka: Asiatic Society of Bangladesh. 24.

Ghisalberti EL, SM Colegate and RJ Molyneux (Eds.), 1993. Detection and isolation of bioactive natural products. CRC Press, Boca Raton, pp. 15-18.

Hanumanth Kumar G and Pramoda Kumari, J. 2015. Phytochemical analysis of secondary metabolites and antimicrobial activity of Sansevieria roxburghiana. World Journal of Pharmaceutical Research, 4: 10721077.

Maroyi A, 2019. Sansevieria hyacinthoides: a review of its botany, medicinal uses, phytochemistry, and biological activities. Asian J. Pharm. Clin. Res., 12: 21-26.

Maroyi A and Mosina GK, 2014. Medicinal plants and traditional practices in peri-urban domestic gardens of the Limpopo Province, South Africa. Indian J. Ind. Knowl., 13: 665-672.

Meyer BN, NR Ferrighi, JE Putnam, LB Jacobsen, DE Nichols and JL McLaughlin, 1982. Brine shrimp: a convenient general bioassay for active plant constituents. Planta. Med., 45: 31-34.

Miller HE, F Rigelhof, L Marquart, A Prakash and M Kanter, 2000. Antioxidant content of whole grain breakfast cereals, fruits and vegetables. J. Am. Coll. Nutr., 19: 312S-319S.

Mosina GKE, A Maroyi and MJ Potgieter, 2015. Useful plants grown and maintained in domestic gardens of the Capricorn district, Limpopo Province, South Africa. Ethno Med., 9: 43-58.

Mwachala G, PK Mbugua, HJ Beentje, SA Ghazanfar (Edts), 2007. Dracaenaceae. In: Flora of Tropical East Africa 1. London: Royal Botanic Gardens, Kew; pp. 10-41.

Semenya SS and MJ Potgieter, 2014. Medicinal plants cultivated in bapedi traditional healers homegardens, Limpopo Province, South Africa. Afr. J. Tradit. Complement Altern. Med., 11: 126-132.

Sethi P, 2013. Biological characterization of the rhizome of Sansevieria roxburghiana Schult. \& Schult. f. (Agavaceae). Journal of Medicinal Plants Research, 7: 1201-1203.

Rieser MJ, ZM Gu, XP Fang, L Zeng, KV Wood and JL McLaughlin, 1996. Five novel mono-tetrahydrofuran ring acetogenins from the seeds of Annona muricata, J. Nat. Prod., 59: 100-108.

Schaffner JH, 1930. Geographic distribution of the species of Equisetum in relation to their phylogeny. American Fern Journal, 20: 89-106.

Sultana N, MM Rahman, S Ahmed, S Akter, MM Haque and S Parveen, 2011. Antimicrobial compounds from the rhizomes of Sansevieria hyacinthoides. Bangladesh J. Sci. Ind. Res., 46: 329-326.

Tkachenko H, L Buyun, P Pażontka-Lipiński, M Witaszek, M Maryniuk and Z Osadowski, 2017a. Extract Obtained from Leaves of Sansevieria hyacinthoides (L.) Druce Reduced Oxidative Damage of Proteins in Equine Erythrocytes. Medicinal Herbs: from Past Experience to New Technologies. Pospelov SV, editor. Poltava: Proceedings of Sixth International Scientific and Practical Conference Dec., 26-27; p. 206-211. 
Tkachenko H, L Buyun, P Pażontka-Lipiński, M Witaszek and Z Osadowski, 2017b. In vitro protective effect of extracts obtained from various Sansevieria species against oxidative damage of proteins in equine erythrocytes. Słupskie Prace Biol., 14: 247-265

Tkachenko H, L Buyun, Z Osadowski and M Maryniuk, 2017c. The antibacterial activity of certain sansevieria thunb. species against Escherichia coli. Agrobiodiversity, 446-453.

Waricky R and W Hoehne, 1951. Chemical Abstracts, 46: 10548e.

Zhao G, Y Hui, JK Rupprecht, JL McLaughlin and KV Wood, 1992. Additional bioactive compounds and trilobacin, a novel highly cytotoxic acetogenin, from the bark of Asimina triloba. J. Nat. Prod., 55: 347-356.

Zobolo AM and QN Mkabela, 2006. Traditional knowledge transfer of activities practised by Zulu women to manage medicinal and food plant gardens. Afr. J. Range. Forage. Sci., 23: 77-80. 